\title{
North as a Sacred Direction? Traces of a Prehistoric North-South Route Across Pembrokeshire
}

\section{Olwyn Pritchard}

\begin{abstract}
The King's Quoit dolmen perches precariously halfway up a headland in south Wales. Its location has been an enigma since Victorian times. The monument builders chose not the spectacular sea views of the south-facing slope, but the apparently more mundane inland vista of the north side, with a near horizon comprising a low ridge on the far side of a small valley, now a beach. Previous research by the author into the astronomical possibilities at this site have revealed horizon indicators for cardinal north, in the form of earth mounds which appear to have marked the lower culminations of Deneb and Vega, as they dipped down to the horizon and rose again during the third and fourth millennium BCE. This has led to another discovery, namely, that a still traceable route way of roads and footpaths leads north from this monument across Pembrokeshire, passing close by several Neolithic monuments and settlements as it does so, before reaching a sheltered bay and another, south facing, dolmen on the north coast. The southern end of this possible ancient trackway is located on Carmarthen Bay, and the northern end, on Cardigan Bay. Both bays encompass a lengthy stretch of relatively sheltered coastal and estuarine water.
\end{abstract}

\section{Introduction}

The King's Quoit dolmen at Manorbier in southwest Wales seems strangely placed. Built on a ledge halfway up a steeply sloping headland, its location has puzzled archaeologists since Victorian times. The monument builders chose not the spectacular sea views and sunny aspect of the south-facing slope, but the apparently more mundane inland vista of the north side, with a near horizon comprising a low ridge on the far side of a small valley, now a beach.

Previous research by the author into the archaeoastronomy of this site revealed possible markers for cardinal north, in the form of a conjunction of the local horizon, as seen from the front of the monument, with the

Olwyn Pritchard, 'North as a Sacred Direction? Traces of a Prehistoric NorthSouth Route Across Pembrokeshire', Culture and Cosmos, Vol. 17, no. 2, Autumn/Winter 2013, pp. 59-76.

www.CultureAndCosmos.org 
lower culminations of the circumpolar stars Deneb and Vega, as they would have been observed during the third and fourth millennium BCE. ${ }^{1}$

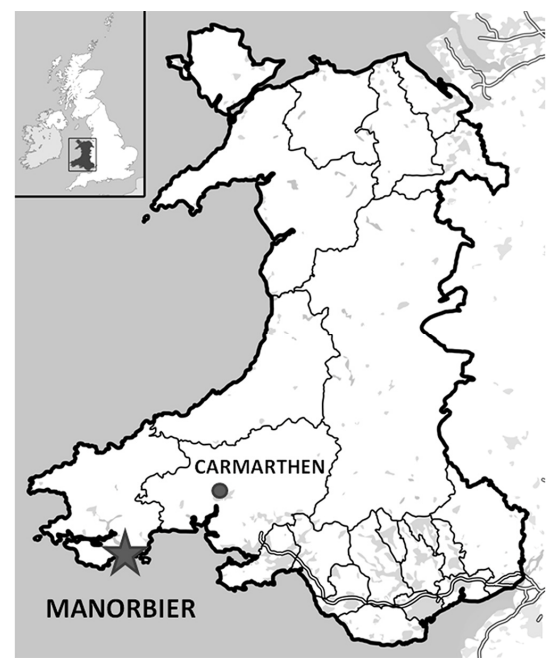

Fig. 1. Location map showing position of Manorbier in south Pembrokeshire.

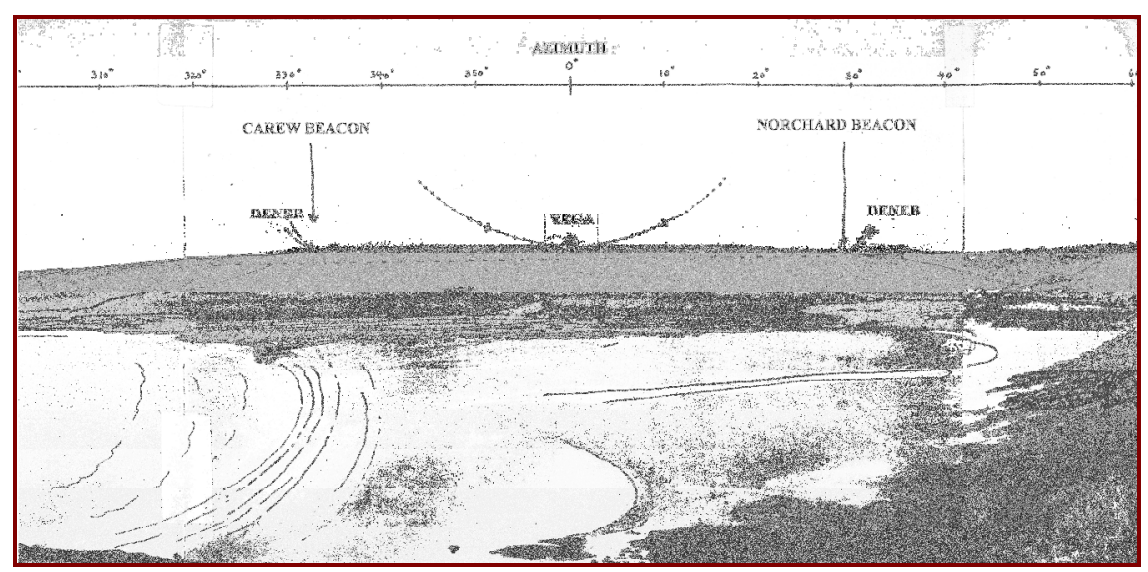

Fig. 2. Artist's impression of the northern horizon at Manorbier, as viewed from the dolmen, on winter nights during the Neolithic and Early Bronze Age. (Illustration by the author, from her own photograph).

${ }^{1}$ O. Pritchard, 'The Circumpolar Skyscapes of a Pembrokeshire Dolmen', in Fabio Silva and Nicholas Campion, eds. Skyscapes: The Role and Importance of the Sky in Archaeology (Oxford: Oxbow Books, 2015), pp. 106-19.

Culture and Cosmos 
Vega would have just brushed the low ridge on the far side of the valley. Deneb's setting and rising points appear to be marked by two groups of mounds set on an east-west trending ridge of high ground about $3 \mathrm{~km}$ inland. For an observer standing at the dolmen, this second ridge is just obscured by the nearer ground, but immediately becomes visible to a traveller climbing up the slope on the north side of the beach. From this point, a road leads northwards to the second, inland ridge, and looking north again from here, the Preseli hills may be seen on the horizon.

Extending this alignment northwards again, beyond the ridge and across the peninsula, has led to another discovery, which is that a still traceable route way of roads and footpaths leads north from this monument across Pembrokeshire, passing close by several other Neolithic monuments and settlements as it does so, before reaching a sheltered bay and another, south facing, dolmen on the opposite, north facing coast of the peninsula. This second monument, Carreg Coetan Arthur, lies almost due north of the King's Quoit. Manorbier at the southern end forms a sheltered harbour, as does Newport at the northern end on Cardigan Bay.

\section{The Concept of a Transpeninsular Route:}

The traditional functional concept of transpeninsular routes is discussed in E. G. Bowen's 1969 book Saints Seaways and Settlements. ${ }^{2}$ Bowen drew on the earlier work of archaeologists such as Cyril Fox, Lily Chitty, Glyn Daniel, and O. G. S. Crawford. ${ }^{3}$ They theorised that the distribution patterns of prehistoric artefacts such as pottery, bronze axes and monuments throughout northwest Europe suggested that people used a network of well-travelled sea routes. Bowen studied these 'trade routes' and showed that they were the same routes later followed in the early medieval by the wandering Christians who became known as saints, which

\footnotetext{
${ }^{2}$ E. G. Bowen, Saints Settlements and Seaways in the Celtic Lands (Cardiff: University of Wales Press, 1969). See also, E. G. Bowen, Britain and the Western Seaways (Thames and Hudson, 1972).

${ }^{3}$ Cyril Fox, The Personality of Britain (Cardiff, 1959); Lily Chitty, 'Notes on the Irish Affinities of Three Type 1a Bronze Age Food Vessels found in Wales' Bulletin of the Board of Celtic Studies (1938), and 'Irish Bronze Age Axes Assigned to the Guilsfield Hoard, Montgomeryshire', Archaeologia Cambrensis (1965); Glyn Daniel, Megalith Builders of Western Europe (London: Harper and Collins, 1958); O. G. S Crawford, 'The Distribution of Early Bronze Age Settlements in Britain', Geographical Journal 40 (1912): pp. 184-203, and 'Western Seaways', in D. Buxton, ed., Custom is King: Studies in Honour of R. R. Marett (1936), pp. 181-200.
} 
suggests that at this time, the routes were as much spiritual pathways as trade routes. ${ }^{4}$ Cunliffe also developed and expanded these theories in 'Facing the Ocean'.

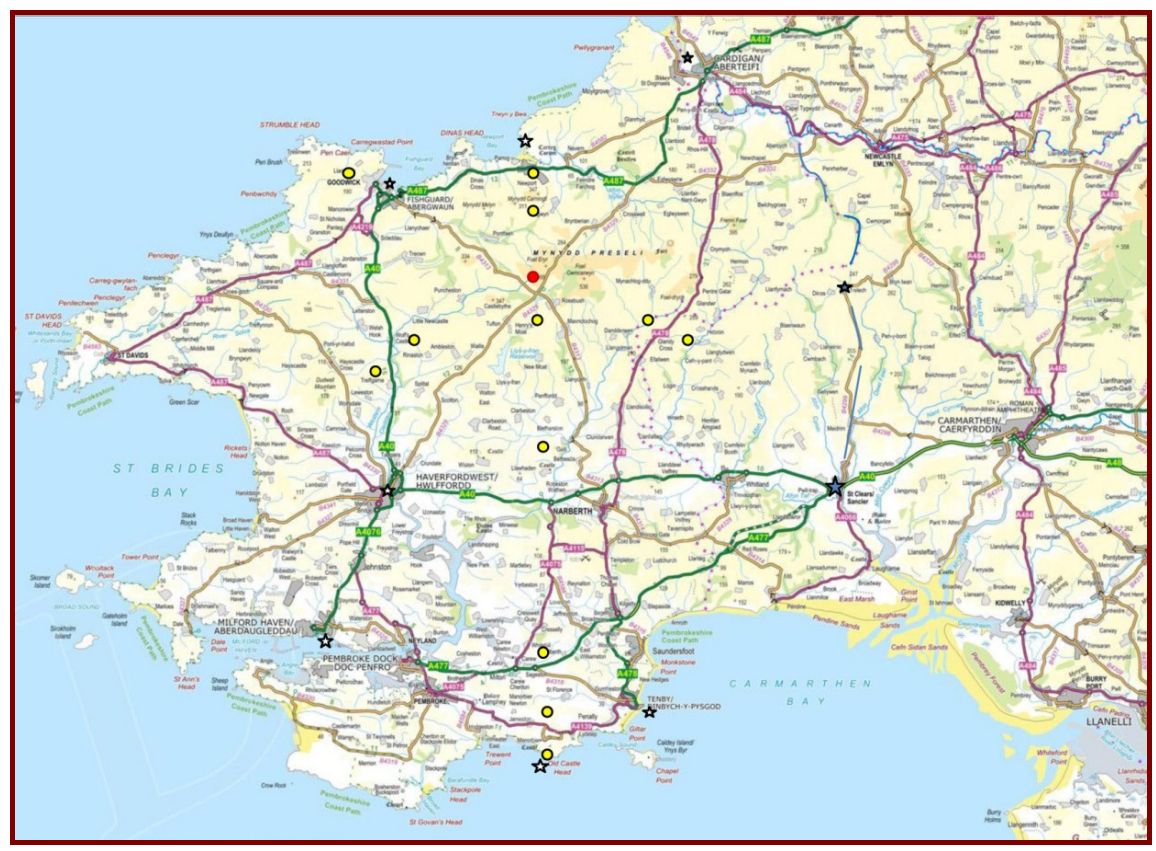

Fig. 3. Map of Pembrokeshire and part of Carmarthenshire, showing possible transpeninsular routes of early origin, and their accompanying monuments/ monument complexes, marked by black and yellow circles. The Neolithic causewayed enclosure, Banc Ddu, is marked by a red dot, and Bowen's suggested Taf-Teifi route is shown in blue. Stars mark locations referred to in the text. Modern roads in some cases still broadly follow the prehistoric routes. (Edina Digimap).

A particular feature of these routes was the short haul, coast hugging nature of the seagoing sections, incorporating stretches of overland travel, which avoided rounding the ends of peninsulas. The sea conditions off rocky promontories such as Lands End and the Welsh peninsulas are notoriously difficult, prone to stormy weather, heavy seas and strong currents. Sheltered coastal waters and inlets such as Carmarthen Bay or

\footnotetext{
${ }^{4}$ Bowen, Saints Settlements and Seaways in the Celtic Lands.

${ }^{5}$ B. Cunliffe, Facing the Ocean (Oxford: Oxford University Press, 2001).
}

Culture and Cosmos 
Cardigan Bay are easier for small boats. On the other hand, the inner waters of the bays lack a strong tidal current. Tidal currents have been suggested as an important aid to progress for early human powered craft, so embarking and disembarking from a point towards the end of the peninsula was advantageous from this point of view. ${ }^{6}$ Bowen proposed the existence of a transpeninsular route way across southwest Wales, suggesting that it involved the lower reaches of the Rivers Taf and Teifi, linked by an overland section, via the modern settlements of St Clears, Trelech and Cardigan (see Fig. 3). ${ }^{7}$

I would like to suggest that there was at least one other, very early route running almost due north-south across what is now Pembrokeshire between Manorbier and Newport, and that the arrangement of the monuments at Manorbier, which emphasised the circumpolar northern stars, acted as an astronomically derived sign post.

Still extant roads and paths follow a course almost due north from Manorbier, although not everywhere in a single line - this course deviates, respecting the landforms, and in some places several parallel track ways form a corridor as much as a mile wide, studded with an unusually dense concentration of monuments chronologically spanning the early Neolithic to the Roman period, including a large Neolithic causewayed enclosure, a rarity in Wales.

\section{Parallels Elsewhere}

A similar phenomenon has been noted by Gordon Noble in Scotland, where many early monuments are grouped along the upper Clyde valley, which creates an easy route through the southern highlands. ${ }^{8}$ Noble also found that land bridges across two of western Scotland's peninsulas were accompanied by complexes of Neolithic monuments (at Dunragit and Kilmartin). Sherrat suggests that the Wessex monument complex which incorporates Stonehenge and Avebury can likewise be considered to be situated on a transpeninsular route. ${ }^{9}$ This area of Wiltshire lies between the headwaters of three rivers (all called Avon). Traversing these waterways would allow travellers to cross from the English Channel to the Severn

\footnotetext{
${ }^{6}$ Cunliffe, Facing the Ocean, pp. 36-38.

${ }^{7}$ Bowen, Saints Settlements and Seaways in the Celtic Lands, pp. 79-82.

${ }^{8}$ Gordon Noble, 'Monumental Journeys: Neolithic Monument Complexes and Route Ways across Scotland', in Vicky Cummings and Robert Johnston, eds., Prehistoric Journeys (Oxford: Oxbow, 2007).

${ }^{9}$ A. Sherrat, 'Why Wessex? The Avon route and river transport in later British prehistory’, Oxford Journal of Archaeology 15 (1996): pp. 211-34.
}

Culture and Cosmos 
without rounding Lands End. ${ }^{10}$ Neither Noble nor Sherrat discuss astronomical elements relating to these routes.

The proposed Pembrokeshire route likewise appears to pass through or close by a Neolithic monument complex, with the greatest concentration of sites seven to ten miles inland of the north coast, around a third of the way to the southern end. At seven miles inland of the north coast, the northsouth route crosses the Preseli Mountains, passing alongside the earthworks of Banc Du, the only Neolithic causewayed enclosure known in west Wales. In striking parallel, Noble notes that a causewayed enclosure, similarly a rarity in Scotland, is located in the upper Clyde valley, on the transpeninsular route he identified there. ${ }^{11}$

To the south of Banc Ddu, about two miles from the enclosure but within sight of it, the route passes through what must have been an area of intense ritual activity on the lower slopes and southern fringe of the Preseli mountains, judging by the large number of dolmens, cairns and circles recorded there in antiquity. Sadly only a few of these remain today. One surviving monument is the semi-ruinous stone circle known as Dyffryn or Garn Ochr, which, during the Neolithic and Early Bronze Age, would have offered a good view on winter nights of Deneb dipping below the close northern horizon for a few hours before rising from behind the summit of Foel Eryr (the Hill of the Eagles), north and slightly to the east of Banc Ddu. An especially large stone in the northeast quadrant of the circle appears to line up with the summit of Eryr. Vega would have dipped down low over the northern horizon and risen again but not set. Both these observations could have been made throughout the third and fourth millennium BCE.

\section{Not Just One Route, but a Network ?}

The Preseli Mountains are famous as the source of some of the Bluestones now located at Stonehenge. Both the proposed quarry sites identified recently by Mike Parker Pearson and his team lie within easy walking distance of the Manorbier to Newport route. ${ }^{12}$ Professor R. J. C. Atkinson, in a discussion relating to the transport of bluestones, pointed out that an east-west trackway runs along the top of the ridge, close to the presumed

\footnotetext{
${ }^{10}$ Sherrat, 'Why Wessex?', p. 225.

${ }^{11}$ Noble, 'Monumental Journeys', pp. 65, 67.

${ }^{12}$ Mike Parker Pearson, Bluestone quarry project-2012/2013 excavation report, Presentation at Pembrokeshire Archaeology Day (Pembroke College, Haverfordwest, 23 Nov 2013).

Culture and Cosmos
} 
source outcrops, meeting a roughly north-south transpeninsular route still used now-namely the main A478 road from Cardigan to Tenby, at the eastern end of the ridge. ${ }^{13}$ The Cardigan to Tenby road, like the Manorbier to Newport route, also passes through a major Neolithic and Bronze Age monument complex, around Glandy Cross (SN14302660), see Figure 3. ${ }^{14}$

The similarities between these two roughly parallel routes could suggest a pattern, especially as the road which links Fishguard and Haverfordwest also runs north-south across the peninsula, to the west of the Manorbier/Newport route, and likewise has an area mid way with striking geological features (e.g., Poll Cairn SM95202452) and numerous prehistoric monuments, including arguably the largest dolmen in Wales, Garn Turne (SM97912727, Archwilio, PRN 2409). The Fishguard/ Strumble Head area has a cluster of chambered monuments and the impressive stone row, Parc-y-Meirw (SM99833592), which Thom calculated was aligned on the northern setting point of the minor standstill moon, over Mount Leinster in Wicklow, some 90 miles distant. ${ }^{15}$

As well as the north-south routes, there are signs of early east-west trackways. The path along the Preseli ridge continues westwards beyond Banc Ddu as a minor road to a five way crossroads just east of St David's. In the other direction it seems to have continued over high ground until it met the upper Usk valley, then followed the lower ground to modern Chepstow.

This east-west route meets and crosses the north-south, Manorbier/Newport way at Banc Ddu, as do two other current transpeninsular roads, making this enclosure site a hub at the crossing point of three local transpeninsular routes and the long distance one. The line of the modern A40, which broadly follows the line of a Roman road west of Carmarthen, and the Fishguard/Newcastle Emlyn/Llanllwni route may represent parallels to the old Preseli track.

${ }^{13}$ R. J. C. Atkinson, Stonehenge (London: Hamish Hamilton, 1956), pp. 174-75, $183-86$.

${ }^{14}$ T. Kirk, G. Williams, A. Caseldine, J. Crowther, I. Darke, T. Darvill, A. David, K. Murphy, P. Ward, and J. Wilkinson, 'Glandy Cross: A Later Prehistoric Monumental Complex in Carmarthenshire, Wales', Proceedings of the Prehistoric Society, Vol. 66 (2000), pp. 257-95.

15 A. Thom, Megalithic Sites in Britain (1967; repr. Oxford: Clarendon Press, 1971), p. 159; R. Heath, Bluestone Magic-A Guide to the Prehistoric Monuments of West Wales (Llandysul, Wales: Gomer Press, 2010), p. 101.

Culture and Cosmos 


\section{The Manorbier to Newport Route and the Monuments}

In the following part of this paper I shall give a description of the Manorbier to Newport route as travelled from south to north, with details of the monuments which line it. The objection has been raised by Fabio Silva that the appearance of a roughly linear concentration of monuments stretching across the peninsula may simply reflect a freak of survival, or an act of 'cherry picking'; that originally the distribution of dolmens, earthworks and settlements was equally dense across the entire area, or that those which fall on or near the line have been emphasised by me whereas others which do not, have been overlooked. ${ }^{16}$ This is a reasonable argument which is hard to refute entirely, as antiquarian reports show that many monuments throughout the region have been destroyed in the last two hundred years. What appears now to be a pattern may simply be the result of an accident of survival.

In defence of the reality of this route way, however, I offer the presence of the rare causewayed enclosure, Banc Ddu, at what appears to have become a major cross road, and the recorded destruction of a number of monuments actually on the north-south line to the south of this structure (Archwilio PRN1317), which would have further enhanced it. ${ }^{17}$ There is a definite cluster of Iron Age sites south of this again, unusual in terms of the sheer numbers in a small area, some of which have been excavated, showing much earlier origins. ${ }^{18}$ This area subsequently attracted a Roman fort. $^{19}$

Additionally, there is the presence of two coastal dolmens-Newport and Manorbier-almost exactly north-south of each other above sheltered harbours, where Mesolithic/Neolithic lithic scatters have been found. ${ }^{20}$

\footnotetext{
${ }^{16}$ Fabio Silva, personal communication.

${ }^{17}$ C. T. Barker, The Chambered Tombs of South-West Wales (Monograph 14), (Oxford: Oxbow, 1992), p. 51.

${ }^{18}$ G. Williams, 'Recent work on rural settlement in later prehistoric and early historic Dyfed', The Antiquaries Journal 68 (1988): pp. 30-54; G. Williams and H. Mytum, 'Llawhaden, Dyfed, Excavation of a small group of defended enclosures, 1980-84', British Archaeological Reports 275 (Oxford, 1998).

${ }^{19}$ J. Meek, A Roman Fort at Wiston, Pembrokeshire-Report on First Season's Excavations, Presentation at Pembrokeshire Archaeology Day (Pembroke College, Haverfordwest, 23 November 2013).

${ }^{20}$ For Newport, see: Archwilio, Dyfed Archaeological Trust online database: http://cofiadurcahcymru.org.uk/arch/dyfed/english/dyfed_interface.html \& DAT HER; For Manorbier, see: A. L. Leach, 'Stone Implements from soil drifts and chipping floors etc. in south Pembrokeshire', Archaeologia Cambrensis 68 (1913):
}

Culture and Cosmos 
Both have their long axes aligned in the direction of travel required to reach the other. The presence of two other parallel north-south roads with accompanying monument complexes nearby is also suggestive of a pattern rather than selective vision, and finally, there have been similar routeways identified elsewhere in the UK, for instance in Scotland and Wiltshire. ${ }^{21}$ Further afield, the work of Malville et al. on the Nabta Playa megaliths is especially pertinent as it indicates an apparent concern with the direction of north as well as the use of monuments for navigation during the Neolithic of that region. ${ }^{22}$

\section{The Monuments: From the Southern End, Proceeding North}

The King's Quoit dolmen (SN 06019728), as mentioned at the beginning of this article, is located on a ledge, half way up the north-facing slope of a steep headland, overlooking a sheltered bay. Barker describes its siting as unusual, but refutes suggestions that it is a natural feature, which observation readily confirms it is not. ${ }^{23} \mathrm{~A}$ large roughly rectangular capstone $5.1 \mathrm{~m} \times 2.6 \mathrm{~m}$, of locally occurring conglomerate, is supported at the outer end on two uprights of the same rock. The inner end rests on the ground at the foot of a line of natural rock slabs which run across the hillside, beside a third support, from which the capstone has slipped. The long axis of the capstone runs north-south. The northern, outer edge or 'front' faces the near horizon at the far side of the bay. This horizon has an altitude angle of $8^{\circ}$ as viewed from beside the dolmen, and would have been grazed by the lower culmination of Vega in the early to mid Neolithic. Concurrently Deneb would have set for a few hours behind this slope, and the positions of its setting and rising, as viewed from the dolmen, appear to have been marked by two groups of mounds on a another, parallel ridge, about two miles inland. ${ }^{24}$

pp. 391-432; V. Cummings, 'Myth, Memory and Metaphor: The Significance of Place, Space, and the Landscape in Mesolithic Pembrokeshire', in R. Young, ed., Mesolithic Lifeways (Leicester Archaeological Monographs, 2000), pp. 81-86; and DAT HER.

${ }^{21}$ Sherrat, 'Why Wessex?'; Noble, 'Monumental Journeys'.

22 J. McKim Malville, R. Schild, F. Wendorf, and R. Brenme, 'Astronomy of Nabta Playa', in J. Holbrook et al., eds., African Cultural Astronomy-Current Archaeoastronomy and Ethnoastronomy Research in Africa (New York: Springer, 2007), pp. 131-43.

${ }^{23}$ Barker, The Chambered Tombs of South-West Wales, p. 38.

${ }^{24}$ Pritchard, 'The Circumpolar Skyscapes of a Pembrokeshire Dolmen'.

Culture and Cosmos 
These mounds (e.g., SN07170005, Norchard Beacon) could be reached in less than an hour by a traveller moving northwards inland at normal walking speed. The mounds apparently date from the Early Bronze Age in their current form, but may represent a redevelopment of Neolithic structures - one of several excavated in the 1850s contained a dolmen-like structure with a capstone of similar size and shape to that of the presumed Neolithic Kings Quoit, but oriented east-west (in parallel to the road running along the ridge) ${ }^{25}$ Another mound in the same group produced a highly decorated early Food Vessel, similar to Irish ceramics dating from 1900 to $2300 \mathrm{BCE}^{26}$

Continuing north, the next surviving early monument is some five miles inland, across easy rolling terrain. This is another dolmen, known as the Cuckoo Stones (SN0646 0387), standing on the side of a gentle valley, above a stream, on an east-facing slope, at $25 \mathrm{~m}$ OD. Barker finds it a confusing structure, having apparently too many stones for one simple chamber. ${ }^{27}$ Nevertheless, it may be found listed on the Archwilio database (PRN 2523) as a Neolithic chambered tomb, and there is certainly a chamber, formed by a capstone propped on uprights, with the open end facing SE, roughly in the direction of winter solstice sunrise. Close by, a stretch of road runs north-south for about two miles and, from the top of the slope north of the dolmen, the summit of the highest Preseli Mountain, Foel Cwm Cerwyn may be glimpsed on the horizon.

From here, continuing north, there are no surviving monuments for around seven miles. The line of the north-south route appears to be followed by the modern A4075, traversing more rolling arable fields with wooded valleys and distant views of Preseli from the higher points.

The point where the A4075 meets the east-west trending A40, at Canaston Bridge (SN06661516), marks the southern edge of a notable concentration of defended enclosures, the density of which can be appreciated by viewing the DAT Archwilio map of the area, and selecting for Iron Age sites.

The line of the north-south transpeninsular route continues north through or close by Llawhaden, now the site of a ruined stone $12^{\text {th }}$ century castle (SN0728171746), once the seat of the bishops of St David's, built on

\footnotetext{
25 J. Deardon, 'Some Remarks on the Opening of Certain Tumuli Near Tenby', Archaeologia Cambrensis (1851): pp. 291-94, here, p. 293.

${ }^{26}$ A. Brindley, The Dating of Food Vessels and Urns in Ireland (Galway: National University of Ireland, 2007), p. 75.

${ }^{27}$ Barker, The Chambered Tombs of South-West Wales, p. 47.
}

Culture and Cosmos 
the site of an Iron Age defended enclosure. Three miles to the west of Llawhaden lies Wiston, with a motte and bailey castle (SN02261817), also placed within what appears to be a prehistoric enclosure. Recently a Roman fort (SN02501864) has been discovered close to Wiston's medieval remains, straddling an extant road running north-south, with the disused but confirmed Roman road from Carmarthen crossing at right angles-i.e., east-west, adjacent to the fort. ${ }^{28}$

Altogether seventeen Iron Age enclosures are grouped around a twomile stretch of the transpeninsular route line between the A40 and a steep scarp north of Wiston at Drim (SN06681932). Known as the 'Llawhaden Group', a number of these sites have been excavated. The earliest dateable occupation evidence found was mid-Bronze Age (1500-1300 BCE), from charcoal in pits sealed by pre-rampart soil at three enclosures, Holgan (SN07331818) and nearby Pilcornswell and Woodside. ${ }^{29}$ There are also several round mounds in hilltop positions within this area, and single standing stones suggestive of Bronze Age occupation, although none of these sites have been excavated. The enclosures all showed evidence of Iron Age occupation, in some cases extending into the Roman period.

It would seem that this area of the Manorbier to Newport route represented a centre of settlement traversed by north-south and east-west roads during the Iron Age and Roman era. It is also situated between the two arms of the River Cleddau, which flows into the drowned valley of Milford Haven, making it accessible from the sea by boat as well as over land. There are no remaining recognisable Neolithic monuments but, as stated, there are signs of Bronze Age activity.

Descending from the scarp, from which the Preseli Mountains may be seen on the horizon, several linked parallel minor roads lead northwards. Five miles brings the traveller to the area of New Moat, Henry's Moat, and Bernard's (Brynach's) Well (SN05402800), where the remains of a Neolithic/Bronze age ritual complex sit at the southern edge of the Preseli massif, in an area of powerful and abundant springs. Antiquarian reports tell of multiple dolmens and stone circles in this general area. ${ }^{30} \mathrm{~A}$ dolmen (Holmus Cromlech) was blown up here by a farmer as recently as 1997 (Archwilio, PRN 1317). The Dyffryn circle (SN05882846) survives in a

${ }^{28}$ Meek, A Roman Fort at Wiston.

${ }^{29}$ Williams, 'Recent work on rural settlement'; Williams and Mytum, 'Llawhaden, Dyfed, Excavation'.

${ }^{30}$ W.J. Phillips, 'Stone Circle, Maenclochog', Archaeolgia Cambrensis (1910): p. 486; Rev. D. Bushell, 'Amongst The Prescelly Circles', Archaeologia Cambrensis (1911): pp. 300-307. 
semi-ruinous state on the southern side of Bernard's Well Mountain, a low, rounded rock-strewn hill. Climbing to the top gives an excellent view of Banc Ddu (SN06043071), looming up on the northern horizon, although the enclosure is concealed from the circle itself.

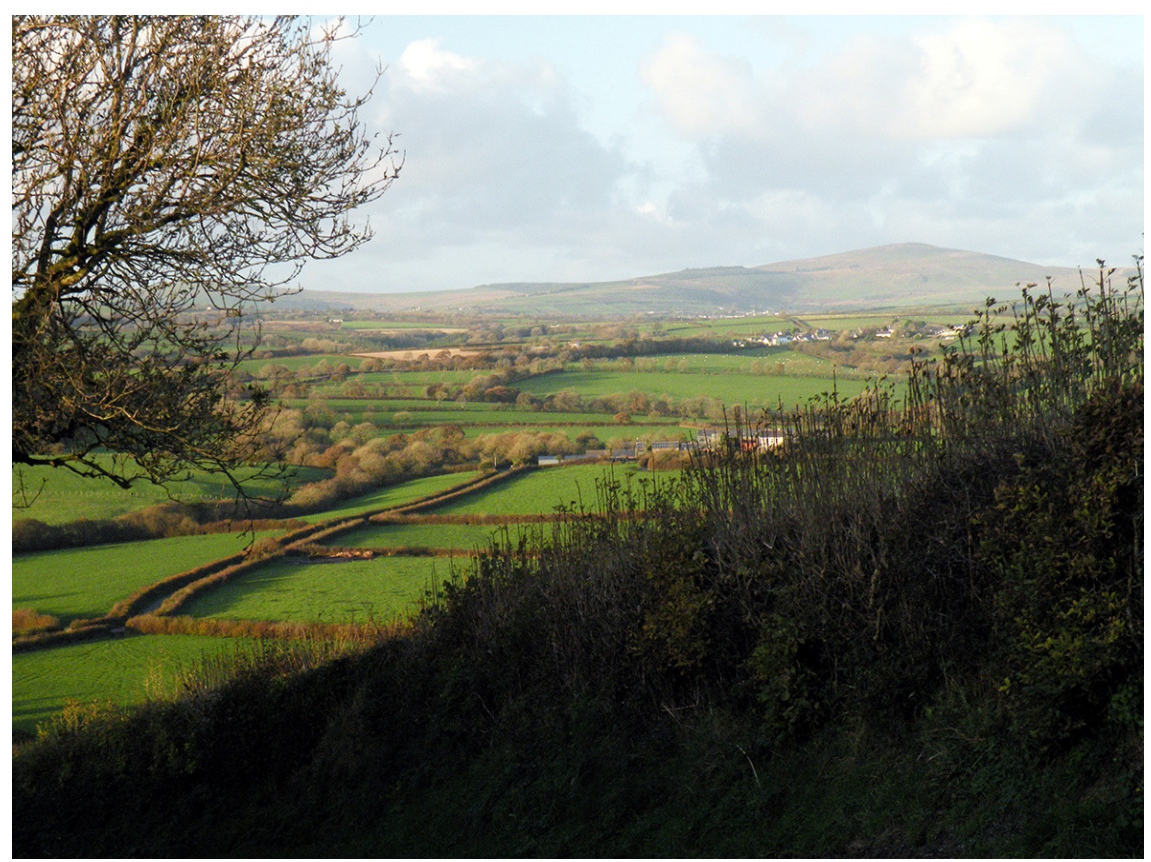

Fig. 4. The Preseli Mountains on the northern horizon, as seen from the scarp near Drim.

Tim Darvill and Geoff Wainwright surveyed Banc Du in 2005 and found the defences irregular, partly interrupted, and not characteristic of the typical Iron Age hill forts of the region. They opened a trial trench across a section of ditch which provided enough material to get Radio Carbon dates from the initial silts which had accumulated in the bottom. These showed that the ditch was open around 3650 BCE. Banc Ddu is the first confirmed such Neolithic enclosure in Wales and it is also notable for the fact that visible earthworks still survive above ground level. ${ }^{31}$

To the north of Banc Ddu, the summit of Foel Eryr rises the west side of a pass through the Preseli ridge, at the point where the east-west ridge

\footnotetext{
${ }^{31}$ T. Darvill, G. Wainwright, and T. Driver, 'Among Tombs and Stone Circles on Banc Du’, British Archaeology (January/February 2007): pp. 26-29.
}

Culture and Cosmos 
route mentioned by Atkinson meets the modern B4329 road joining Cardigan and Haverfordwest. The most direct route north to the mouth of the River Nevern, and Carreg Coetan Arthur dolmen, however, passes around the lower slopes of the hill on its western side, following a footpath, which drops down into the upper reaches of the Gwaun valley, crossing the river at Llanerch (SN05703543). The way then ascends the south-facing slope, to pass across Carn Ingli common, and below the notable rocky outcrop of Carn Ingli (SN06293729). To quote Toby Driver of the RCAHMW,

The stone-built ramparts, enclosures, huts and fields [on Carn Ingli] clearly have their origins in prehistory but, as yet, no excavations have shed light on the development of one of the largest hill forts in west Wales. Three conjoined enclosures on the highest point, are probably the result of multiple periods of early occupation and enlargement. A fourth larger enclosure extends to the north onto lower ground and is crowded with stone-built huts and pounds and even the remains of an old street or track. There are twelve gateways, a very high number of vulnerable openings to defend if we assume the structure is an Iron Age hill fort, and it may be that parts of Carn Ingli date back far earlier, to the Neolithic or Bronze Age. ${ }^{32}$

The surrounding area of Carn Ingli Common is also rich in hut circles, cairns and tracks of probable prehistoric origin. ${ }^{33}$

The name Carn Ingli translates as the hill or rock of the angels, becoming associated in the middle ages with St Brynach, whose name may be derived from the welsh for hill, 'bryn', and 'iechyd', healing or healthy, and whose church nearby with rock cut cross in the hillside above was an essential way-station for pilgrims en route to St David's.

Brynach's Well and church at Henry's Moat (SN04412574), to the south of Banc Ddu, are also close to the line of the transpeninsular route.

Below Carn Ingli, where the transpeninsular route meets the Nevern estuary, stands the last (or first) dolmen, Carreg Coetan Arthur (SN06023936), facing slightly east of south, in the direction of midwinter sunrise, which is also the direction taken by the extant minor road from Newport toward Carn Ingli and the south.

\footnotetext{
32 Toby Driver, Pembrokeshire Historic Landscapes from the Air (Aberystwyth: RCAHMW, 2008), pp. 122-24; Coflein - RCAHMW online database http://www.coflein.gov.uk.

${ }^{33}$ Driver, Pembrokeshire Historic Landscapes.
} 
Heath notes that the dolmen's location marks the point where the midsummer full moon at the lunar standstill can be seen to emerge from behind Carn Ingli, and roll along the adjoining ridge. ${ }^{34}$ Additionally, the author has confirmed by her own measurements taken inside the monument that if originally open as it now stands, it represents a portal for the midwinter rising sun/summer solstice setting sun to shine through along its long axis, while the midsummer rising sun/midwinter setting sun would shine through from side to side.

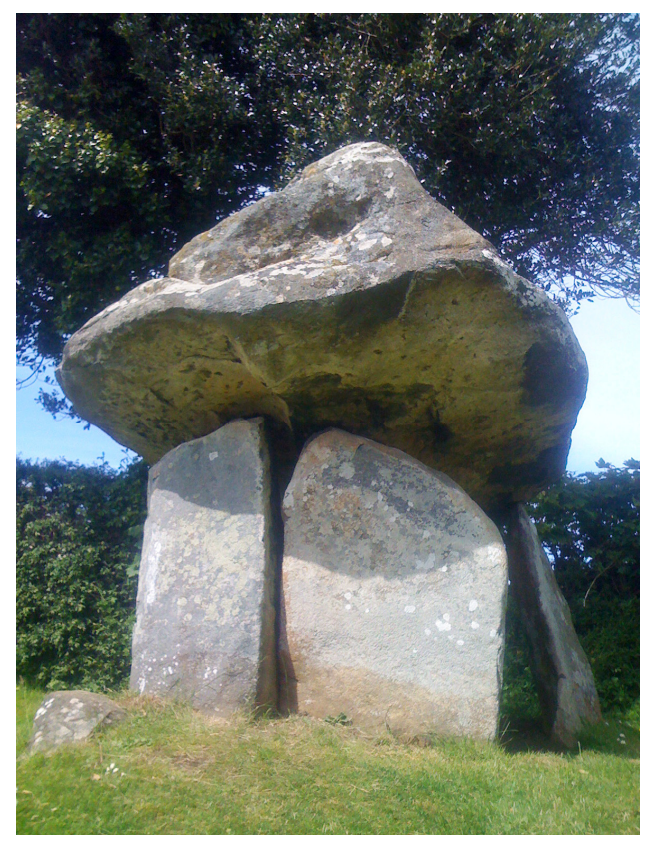

Fig. 5. Carreg Coetan Arthur dolmen at Newport Pembrokeshire.

The area around the dolmen was excavated by Sian Rees in 1980 and no evidence of a covering mound was seen. Charcoal from secure contexts beneath the floor of the structure gave dates of around $3500 \mathrm{BCE}$. This site also produced sherds from four round-bottomed bowls, considered to be broadly contemporary, similar to bowls found at other securely dated early Neolithic sites in the region. ${ }^{35}$

\footnotetext{
${ }^{34}$ Heath, Bluestone Magic, p. 105.

${ }^{35}$ S. Rees, Dyfed, Cadw Welsh Historic Monuments Series (HMSO, 1992), pp. $15-16$.
}

Culture and Cosmos 
From here it is a few yards only to the tidal waterway leading out into Cardigan Bay, while the shores of the estuary itself have yielded numerous pieces of Mesolithic/Neolithic worked flint. ${ }^{36}$

\section{Discussion - the significance of the Manorbier to Newport route.}

The modern road network presumably follows much older routes for most of its length, and we can see that there are a number of ways to cross this western peninsula. The Manorbier to Newport route is only one of several, and the only one not now followed by a main road for most of its length. The reason for this is possibly that it is not the easiest or shortest, suggesting that its original purpose may have been as much ceremonial and symbolic, as practical.

The concept of prehistoric pilgrimage has been discussed by Harding, Bradley, Edmonds, Thomas and Tilley, among others. ${ }^{37}$ That long distance journeys were being made in Britain during the Neolithic is suggested by the discovery of cattle bones and teeth at Durrington Walls in Wessex dating to around $3000 \mathrm{BCE}$, which, following isotopic analysis, were found to have originated in Wales and/or possibly Scotland. ${ }^{38}$ The frequent discovery of Neolithic stone axes far from their point of origin could be explained by trade or exchange, but could also suggest a high degree of mobility among their owners. ${ }^{39}$

The decision to travel in a particular direction may derive from ideas of the sacredness of a certain orientation. For instance, Bradley found that among the Saami of northern Europe, each of the cardinal directions

\footnotetext{
${ }^{36}$ Archwilio.

${ }^{37}$ J. Harding, 'Later Neolithic Ceremonial Centres, Ritual and Pilgrimage-The Monument Complex of Thornborough, North Yorkshire', in A. Ritchie, ed., Neolithic Orkney in its European Context (Cambridge: MacDonald Institute for Archaeological Research, 2000), pp. 31-46; J. Harding, B. Johnston, and G. Goodrick, 'Neolithic Cosmology and the Monument Complex of Thornborough, North Yorkshire', Archaeoastronomy 20 (2006): pp. 26-51; R. Bradley, 'Pilgrimage in Prehistoric Britain?', in J. Stopford, ed., Pilgrimage Explored (Woodbridge, Suffolk: York Medieval Press, 1999); M. Edmonds, Ancestral Geographies of the Neolithic (London: Routledge, 2002); J. Thomas, Rethinking the Neolithic (Cambridge: Cambridge University Press, 1991); C. Tilley, A Phenomenology of Landscape: Places, Paths and Monuments (Oxford: Berg, 1994).

${ }^{38}$ Mike Parker Pearson, Stonehenge (Simon and Schuster, 2012), pp. 120, 121.

39 Edmonds, Ancestral Geographies of the Neolithic; Bradley, 'Pilgrimage in Prehistoric Britain?'; Thomas, Rethinking the Neolithic.
} 
assumed a special significance. ${ }^{40}$ The direction of north was associated with the sacred, with men, wild animals and winter. The northern sky contains the highest point of their 'cosmic river' or world tree, which connects the three layers of the Saami cosmos, consisting of sky, earth and underworld.

Sacred places in the landscape where votive offerings might be made were in many cases 'located along the routes by which people travelled at different times of the year', and were often additionally marked out by unusual or striking topography. ${ }^{41}$

Gordon, in his paper on orientation, mentions that in contrast to the now more common (Judaeo/Christian influenced) preference for east as a sacred direction, some other traditions hold north as the most sacred of all directions. ${ }^{42}$ The Gnostics or Dualists were one example-according to the Gnostics, light, beneficence and revelations came toward our terrestrial world from the north. The Mandaeans of Iran and Iraq face north if they want to think deeply, and the Manichees of third-century Persia (now Iran) considered that their Tree of Life stood in the north. The Chinese meanwhile still favour south as the most auspicious direction. ${ }^{43}$ That cardinal directionality has had significance in the cosmologies of many different cultures past and present (in fact, according to Gordon, almost all cultures) can additionally be seen by the attention paid to the cardinal alignment of square prehistoric structures in India, such as Mohenjo-Daro and Hanamsagar. ${ }^{44}$

North has its own special place for the Saami, and may have had significance for the early Neolithic (4500-3600 BCE) inhabitants of Nabta Playa, in what is now southern Egypt, where a stone circle and a number of stone rows indicate north. Anthropomorphically-shaped stone slabs stand in the sand, and as well as creating north-south alignments, themselves face roughly north. Other directions indicated at this spot include the

${ }^{40}$ R. Bradley, An Archaeology of Natural Places (London and New York: Routledge, 2000), p. 12.

${ }^{41}$ Bradley, An Archaeology of Natural Places, p. 6.

${ }^{42}$ B. L. Gordon, 'Sacred Directions, Orientation, and the Top of the Map', History of Religions 10, no. 3 (1971): pp. 211-27.

${ }^{43}$ Gordon, 'Sacred Directions', pp. 218, 219.

44 Gordon, 'Sacred Directions', p. 211; S. Kak, 'Visions of the Cosmos: Archaeoastronomy in Ancient India', Journal of Cosmology 9 (2010): pp. 206377.

Culture and Cosmos 
winter solstice sunset/summer solstice sunrise, and the rising points of various stars. ${ }^{45}$

There are two possible ways to view the Manorbier to Newport route. There is the more functional interpretation which regards such transpeninsular tracks as a way for travellers and traders to avoid the stormy seas off the western headlands, and there is the ritual/ceremonial approach. The latter does not necessarily exclude the former, but in the case of this proposed route there are alternative shorter ways to cross the peninsula. The apparent emphasis on the northern stars, especially Deneb and Vega at Manorbier, is reflected in the linear directionality of the subsequent pathway, leading ultimately to another dolmen facing landwards at its northern end. This could suggest that Neolithic, and perhaps even earlier, peoples living in this region, made a deliberate choice at certain times to follow a north-south path, marked out by the polar stars at night and the sun by day, as it seems the Saami and perhaps those who built the Nabta Playa also did, and that these celestially-based journeys were as much ceremonial as functional. Marking the track with monuments would reinforce this sacred focus.

\section{Conclusion}

It appears that during prehistory, a north-south routeway, marked initially by Neolithic monuments, and passing through a central monument complex, stretched between a dolmen on the south coast, and another on the north coast of Pembrokeshire. The nature of the monuments and subsequent additions suggest that they provided a focus for gatherings, ritual activity and settlement which continued into the Medieval period.

For the purposes of trade and travel, if transporting goods or carrying boats, this route would not be as easy or as short as going via Carmarthen or St Clears to the Teifi. However the concentration of monuments from all periods suggests that it was by no means the road less travelled. Perhaps it had something of the pilgrimage about it, making its difficulty irrelevant, or even part of its attraction, in the same way that rock outcrops favoured during the Neolithic for quarrying axe material seem often to have been the highest and most inaccessible. ${ }^{46}$

More work needs to be done, but it may be that the very act of moving in the cardinal directions, as suggested by the apparent remains of an eastwest and north-south network of early routes in Pembrokeshire, was in

\footnotetext{
${ }^{45}$ Malville et al., 'Astronomy of Nabta Playa'.

${ }^{46}$ Edmonds, Ancestral Geographies of the Neolithic.
} 
76 North as a Sacred Direction?

some way a significant act. Alternatively at the very least it would allow for simple navigation by landmarks, sun and stars, a system which even children could grasp, in a time before compasses and maps. Or perhaps some combination of the two, a mystery for the reader to ponder.

Culture and Cosmos 